\title{
Comparison of Results between Cytogenetic Technique and Molecular Genetic Technique in Colorectal Carcinoma Patients
}

\author{
Cheolin Park ${ }^{1}$, Jae Sik Lee ${ }^{2}$ \\ ${ }^{1}$ Department of Biomedical Laboratory Science, Daegu Health College, Daegu, Korea \\ ${ }^{2}$ Department of Clinical Laboratory Science, Hyejeon College, Hongseong, Korea
}

\section{대장암환자의 염색체 결실에서 세포유전학적 기법과 분자유전학적 기법의 결과 비교}

\author{
박철인 ${ }^{1}$, 이재식 ${ }^{2}$ \\ ${ }^{1}$ 대구보건대학교 임상병리과, ${ }^{2}$ 예전대학교 임상병리과
}

\begin{abstract}
Globally, 1.3 million people develop colon cancer every year, and 600,000 people die each year it. In Korea, colorectal carcinoma was associated with the highest death rate, accounting for 8,380 people, among solid cancers in 2015. Among the various methods for the diagnosis and study of colorectal carcinoma, the results obtained by cytogenetic and molecular genetic methods were compared. Detection rate was $47 \%$ in $18 \mathrm{q}, 40 \%$ in $17 \mathrm{p}, 27 \%$ in $22 \mathrm{q}$, and $17 \%$ in $10 \mathrm{q}$ via CGH; detection rate was $57 \%$ in D18S59, 50\% in D18S68, 50\% in TP53CA, 47\% in D18S6940\% in D22S274, 37\% in D22S283, 27\% in D10S187, and 23\% in D10S541 with LOH. Microsatellite marker matching rates were $100 \%$ in D22S274, 100\% in D22S283, 100\% in D10S186, 100\% in D10S187, 100\% in D10S541, 93\% in D18S69, 93\% in D18S68, 92\% in TP53CA, and 89\% in D18S59. The agreement rate between the two methods was $94.4 \%$ based on positive results using $\mathrm{CGH}$. Based on the advantages of $\mathrm{CGH}$, which was the ability to obtain information regarding the entire tumor genome at once, this experiment could identify the region with significant deletion using CGH and the more limited region $\mathrm{LOH}$, with a completely different approach. $\mathrm{LOH}$ in the recurrent high-risk group, $18 \mathrm{q} 21$, was helpful in the selection of treatment modalities and in prognostic estimation as well as making the most appropriate decision for treatment. Therefore, it is suggested that $\mathrm{LOH}$ with surgical site tissues could be one of the treatment methods for recurrent high-risk group among patients with colorectal carcinoma.
\end{abstract}

Key words: Colorectal carcinoma, Comparative genomic hybridization, Deletion, Loss of heterozygosity, Microsatellite marker

\footnotetext{
This is an Open Access article distributed under the terms of the Creative Commons Attribution Non-Commercial License (http://creativecommons.org/licenses/by-nc/4.0) which permits unrestricted non-commercial use, distribution, and reproduction in any medium, provided the original work is properly cited.

Copyright @ 2017 The Korean Society for Clinical Laboratory Science. All rights reserved.
}

Corresponding author: Jae Sik Lee Department of Clinical Laboratory Science, Hyejeon College, 25 Daehak-gil, Hongseongeup, Hongseong 32244, Korea

Tel: 82-41-630-5340 Fax: 82-41-634-5154

E-mail: jslee@hanmail.net

Received: July 11, 2017 Revised $1^{\text {st: }}$ July 28, 2017 Revised 2nd: August 4, 2017

Revised $3^{\text {rd: }}$ : August 7, 2017 Accepted: August 7, 2017

\section{INTRODUCTION}

The incidence of colorectal carcinoma which is ranked the second for female and the third for male has been reported total 614,000 women and 746,000 male in the entire world annually [1,2]. The mortality from colorectal 
carcinoma is reported to 600,000 peoples annually [3]. In case of Korea, there is a difference with a world report with the second rank for female and the fourth rank for male. However, according to statistics report in the year of 2015, the mortality of stomach cancer shows 16.7 persons per 100,000 and 16.4 for colorectal carcinoma, accounting for 98.2 percent of stomach cancer [4]. However, increased incidence of cancer in the last 10 years indicates a 32 percent increase in colon cancer and stomach cancer decreased by 26 percent. It is expected that the number of cancer rates in Korea will be reversed in the coming years.

Typically, there are dietary factors and genetic factors which are related with an important factor in the occurrence of colon cancer. Molecular biological changes as genetic factors for developing cancer are known to be progressive gene alteration between genes and repressive changes of cancer [5]. In other words, when the cancer gene is activated or the cancer suppressor gene is inactivated, the balance between them is lost and abnormal cell growth is promoted, resulting in cancer [6]. Loss of heterozygosity, analysis relies on the assessment of polymorphic markers, such as microsatellites. In practice, the measurement is of the relative dosage of the maternal allele to the paternal allele at the site of the polymorphism. Comparative genomic hybridization is a cytogenetic technique used in the diagnosis of colorectal carcinoma which detects the change in the number of DNA copies of a tumor gene against a normal gene. This is a convenient method to detect the genetic changes of the whole tumor genome and is widely applied to the study of genetic changes in solid tumors [7]. Loss of heterozygosity method as a molecular genetic technique for diagnosis of colorectal carcinoma, which shows a significant feature of cancer suppressing genes, has been reported. Loss of heterozygosity means the mutation occurrence even if an allele of cancer cells is defective or not deficient. Efforts through Loss of heterozygosity have been tried to find loci for cancer suppressor genes in colorectal carcinoma [8].

In this study, an author investigated the overall genetic changes in Korean colon cancer using the comparison of gene hybridization and performed Loss of heterozygosity with 9 microsatellite markers in 10q, 17p, 18q, and 22q chromosomes with significant deletion in Comparative genomic hybridization, using comparing the results between the two methods. It is identified that thus, by comparing the results of Comparative genomic hybridization, which can select the entire genetic alteration site involved in the development of colorectal carcinoma, and the results of the Loss of heterozygosity test, which can detect gene changes in a small part of all chromosomes and all the chromosomes, can play a major role in the treatment and prognosis.

\section{MATERIALS AND METHODS}

\section{Patients and samples}

For the analysis of comparative genomic hybridization and loss of heterozygosity, 30 tissues of colon cancer patients who were operated on at $\mathrm{K}$ hospital in Busan were received and used in this study. The samples used in this research were complied with the research ethics regulations of the Korean Society of Clinical Laboratory Science. DNA extracted from tumor tissues and DNA from normal human blood were hybridized to normal mid-stage cells. Loss of heterozygosity analysis was performed using DNA obtained from tumor tissues and normal tissues of the same patient, respectively. Among the subjects, 14 were males and 16 were females. The mean age was 55 years (range 32 80). Stage I was found in 2 cases, stage II in 10, stage III in 15, stage IV in 3, and colorectal carcinoma staging was based on American Joint Committee on Cancer (AJCC) criteria. There were 17 cases of hyperplasia type, 8 cases of intermediate type, 3 cases of low type, and 2 cases of mucinous type (Table 1 ).

\section{CGH method}

\section{1) DNA preparation and labeling}

DNA was extracted from tumor tissue using a genomic DNA purification kit (Promega, USA), and from normal male blood using DNAzol genomic DNA isolation reagent (Molecular research center Inc., Cincinaty, USA), respectively. Genomic DNA of normal blood, used as a reference 
Table 1. Clinical findings and pathological diagnosis of colorectal carcinoma cases

\begin{tabular}{lc}
\hline \multicolumn{1}{c}{ Variables } & Number of cases $(\mathrm{N}=30)$ \\
\hline Sex & \\
Male & 14 \\
Female & 16 \\
Location & \\
Right colon & 12 \\
Rectum & 18 \\
CEA (ng/mL) & \\
$\leq 5$ & 16 \\
$\geq 5$ & 14 \\
Maximal size (mm) & \\
$\leq 50$ & 16 \\
$\geq 50$ & 14 \\
Histological classification & \\
Well differentiated & 17 \\
Moderately to poorly differentiated & 11 \\
Mucinous & 2 \\
Lymph node metastasis & \\
Negative & 14 \\
N1 & 12 \\
N2 & 3 \\
N3 & 1 \\
Stage classification & \\
I & \\
II & \\
III & \\
IV & 10 \\
\hline
\end{tabular}

DNA was labeled with digoxigenin-11-dUTP with nick translation kit (Boeringer Manheim, Manheim, Germany). The size of the probe was adjusted to 500 2000 bp on the concentration of DNAse I during the labeling process. Digoxigenin-labeled reference DNA and biotin-labeled tumor DNA were precipitated with ethanol and $20 \mu \mathrm{g}$ of cot-1 DNA (Boehringer Manheim, Manheim, Germany).

\section{2) Preparation of the metaphase chromosome}

Lymphocytes from normal male blood were obtained by phytohemagglutin stimulation and subsequently cultured for 3 days. Slides were prepared by a conventional method. For 4', 6-diamidino-2-phenylindole (DAPI) analysis, samples were stored at $65^{\circ} \mathrm{C}$ overnight and placed at $-20^{\circ} \mathrm{C}$ and then used.

\section{3) Hybridization}

The CGH method was used with a slight modification of Kallioniemi. The probe was prepared with 200 500 ng of labeled-normal DNA and labeled-tumor DNA, respectively. After mixing well, sodium acetate (1/10 volume), 2.5 times ethanol, $10 \mu \mathrm{L}$ Cot-1 DNA, were added and incubated for 2-3 hours at $70^{\circ} \mathrm{C}$. The supernatant was removed after centrifugation at $14,000 \mathrm{xg}$ for $30 \mathrm{~min}$ and the pellets were diluted with $10 \mu \mathrm{L}$ of a hybrid mixture (50\% formamide, 10\% dextran sulfate/2X SSC, pH 7.0). The diluted pellets were denatured at $73^{\circ} \mathrm{C}$ and, then used. Prepared metaphase chromosomes from the above were denatured at $73^{\circ} \mathrm{C}$ for 2 min and, then hybridized for $2 \sim 3$ days.

\section{4) Washing and counterstaining}

Prepared samples were washed three times with 50\% formamide at $45^{\circ} \mathrm{C}$ for $7 \mathrm{~min}$, and subsequently washed a further two times with $2 \mathrm{X} \mathrm{SSC}$ at $45^{\circ} \mathrm{C}$ for $7 \mathrm{~min}$. A final wash in XX SSC at room temperature was followed by a 5 min-preblocking with a preblocking solution (1\% BSA in 2X SSC). Biotinylated DNA was stained with $5 \mu \mathrm{g} / \mathrm{mL}$ of fluorescein isothiocyanate (FITC) conjugated with avidin and digoxigenin-labeled DNA with $1 \mu \mathrm{g} / \mathrm{mL}$ of antidigoxigenin rhodamine, respectively and then counterstained with DAPI.

\section{5) Image analysis}

Hybridized slides were analyzed by an image analyzer, Cytovision system (Applied Image, UK). A fluorescence microscope with an attached triple band pass splitter and emission filter was used. A program for CGH, supplied by Applied Image Co. analysis was also purchased and used. The ratio of the profile was calculated with the fluorescenced ratio between FITC and rhodamine on each chromosome and karyotyping analysis was performed using DAPI-stained chromosomes. Chromosomal regions where the FITC to rhodamine exceeded 1.15 were considered amplification, while those below 0.85 were considered deletion. DNA from normal lymphocytes was labeled with different flourochromes and the value was chosen as the cut-off level after the evaluation of five metaphase-stage cells. Single chromatid or one of two chromosomes showing specific signal-amplification were excluded, considering a non-specific reaction. Telomeric and heterochromatic 
regions were also excluded from the analysis. A fluorescenced ratio exceeding 1.5 means high-level amplification. The mean value was calculated with analysis of at least four chromosomes.

\section{LOH method (Manual method)}

\section{1) DNA extraction}

After cut of tumor and normal tissue, DNA was extracted using a genomic DNA purification kit (Promega Madison, WI, USA). Add nuclei lysis solution and $10 \mu \mathrm{g} / \mathrm{mL}$ of proteinase $\mathrm{K}$ into tissue and place it at $55^{\circ} \mathrm{C}$ incubator to dissolve the tissue completely. RNA was removed with RNAse and protein was precipitated in protein precipitation solution. After transfer the supernatant, gently wash with serial ethanol. Finally, DNA was extracted with DNA rehydration solution. The final concentration of DNA was adjusted with $0.1 \sim 0.9 \mu \mathrm{g} / \mathrm{mL}$ and was finally chosen with the ratio, $1.6 \sim 1.8$.

2) Synthesis of microsatellite oligonucleotide primer

The verified base sequence for primers of cytogenetic localization was found from Genbank of ncbi.nlm.nih.gov and other references. The primers with long and stable sequence, considering for the secondary structure after PCR were designed. The designed and synthesized primers were prepared by GenoTech (Daejeon, Korea) (Table 2).

\section{3) Microsatellite amplification by PCR}

Dilute DNA to be template bring to $50 \mathrm{ng} / \mu \mathrm{L}$ with TE buffer and PCR was performed: DNA $100 \mathrm{ng}, 10 \mathrm{pmol}$ of forward and reverse primer, with the thermocycling conditions set at $94^{\circ} \mathrm{C}$ for $5 \mathrm{~min}$, followed by 30 cycles of $94^{\circ} \mathrm{C}$ for $30 \mathrm{sec}, 72^{\circ} \mathrm{C}$ for $30 \mathrm{sec}$, and $72^{\circ} \mathrm{C}$ for $5 \mathrm{~min}$. PCR was performed 3 times for each primer to get reproducibility and get clear bands under 2\% agarose gel.

\section{4) DNA sequencing gel and electorphoresis}

DNA sequencing gel was acrylamide/bis-acrylamide, urea (Sigma-Aldrich Co., Saint Louis, USA), with $5 \times$ TBE buffer bringing to $6 \%$ polyacrylamide gel with the gel plate of $33 \mathrm{~cm} \times 40 \mathrm{~cm} \times 4 \mathrm{~mm}$ and electrophorized with Model S2 sequencing gel eletrophoresis apparatus (Life Technologies, Seoul, Korea) and prerunned for 1 hour. Denaturated for $5 \mathrm{~min}$ at $94^{\circ} \mathrm{C}$ with the ratio $2: 1, \mathrm{PCR}$ product to loading solution (95\% formamide, $10 \mathrm{mM}$ $\mathrm{NaOH}$, bromphenol blue, xylene blue), respectively. After a rapid cooling on ice and loaded with 1,500 V for 3 hours.

\section{5) Silver staining and Interpretation}

After electrophoresis, gel was stained with silver staining kit (Bioneer, Korea) and applied onto fixing, enhancing, staining and developing. Followed by these four steps, gel plate was dried and saved the image by

Table 2. Primer sequence of the microsatellite markers

\begin{tabular}{|c|c|c|c|}
\hline Markers & Cytogenetic localization & Primer sequence & Annealing temp $\left({ }^{\circ} \mathrm{C}\right)$ \\
\hline D10S186 & $10-10$ & $\begin{array}{c}\text { 5'-TTTGAGAATGTGATGAAGGTCTTGG-3' } \\
\text { 5'-TGAATCTATGAGGACAGGGTGGG-3' }\end{array}$ & 62 \\
\hline D10S187 & $10-10$ & $\begin{array}{c}\text { 5'-TTACTAAGTACAGGGAAGGCG-3' } \\
\text { 5'-TTCCTTAAGAGAGGTTTGGG-3' }\end{array}$ & 57 \\
\hline D10S541 & $10 q 22-10 q 23$ & $\begin{array}{l}\text { 5'-AAGCAAGTGAAGTCTTAGAACCACC-3' } \\
\text { 5'-CCACAAGTAACAGAAAGCCTGTCTC-3' }\end{array}$ & 61 \\
\hline TP53CA & $17 p$ & $\begin{array}{c}\text { 5'-ACTGCCACTCCTTGCCCCATT-3' } \\
\text { 5'-AGGGATACTATTCACCCCGAGGTG-3' }\end{array}$ & 57 \\
\hline D18S59 & $18-18$ & $\begin{array}{l}\text { 5'-GGGGCACAAGACAGATAGAT-3' } \\
\text { 5'-CCTACCAGAATGTGAACGAC-3' }\end{array}$ & 56 \\
\hline D18S68 & $18 q 22.1$ & $\begin{array}{l}\text { 5'-ATGGGAGACGTAATACACCC-3' } \\
\text { 5'-ATGCTGCTGGTCTGAGG-3' }\end{array}$ & 60 \\
\hline D18S69 & $18 q 12-18 q 21.31$ & $\begin{array}{l}\text { 5'-CATTAGCAGTCTGGAAATCCTC-3' } \\
\text { 5'-CGCTATTGTACTGAAAACCTGA-3' }\end{array}$ & 56 \\
\hline D22S274 & 22pter-22qter & $\begin{array}{c}\text { 5'-GTCCAGGAGGTTGATGC-3' } \\
\text { 5'-AGTGCCCATTTCTCAAAATA-3' }\end{array}$ & 62 \\
\hline D22S283 & $22-22$ & $\begin{array}{c}5^{\prime}-\text { ACAAACACTTCTACAGTCCTGG-3' } \\
5^{\prime}-\text { TGAGCCACGGAGATCTTTC- } 3^{\prime}\end{array}$ & 52 \\
\hline
\end{tabular}


computer scanner.

Amplification was decided when an allele from tumor cells increase more 50\% than that of normal cell after measurement of density on each band.

\section{LOH method (Genetic analyzer method)}

1) Synthesis of fluorescence microsatellite oligonucleotide primer

The synthesis of fluorescent primers D18S68 and D18S69 to be used in the genetic analyzer was manufactured by Applied Biosystem (Pensylvania, USA).

2) Microsatellite amplification by fluorescent $P C R$

The PCR using $10 \mu \mathrm{L}$ of AmpliTagGold PCR master mix (Applied Biosystem, USA), $50 \mathrm{ng} / \mu \mathrm{L}$ of template DNA, 7.5 pmol of each fluorescent forward/reverse primer, added to $20 \mu \mathrm{L}$ of ddDW was performed. Cycling was performed in a GeneAmp PCR system 9600 thermocycler (Perkin-Elmer. Boston, USA) with an initial denaturation step of $10 \mathrm{~min}$ at $95^{\circ} \mathrm{C}$; 30 cycles of denaturation $\left(10 \mathrm{sec}\right.$ at $\left.96^{\circ} \mathrm{C}\right)$, annealing (30 seconds at primer specific temperature), extension (3 min at $70^{\circ} \mathrm{C}$ ), and a final extension step at $70^{\circ} \mathrm{C}$ for $30 \mathrm{~min}$.

\section{3) Capillary electrophoresis}

The reaction mixtures for electrophoresis included 0.5 $\mu \mathrm{L}$ of PCR product, $0.5 \mu \mathrm{L}$ of Genescan size standard Applied Biosystem (Pensylvania, USA) and $11 \mu \mathrm{L}$ of formamide Applied Biosystem (Pensylvania, USA) and were mixed well. The mixtures were denatured at $95^{\circ} \mathrm{C}$ for $5 \mathrm{~min}$ and subsequently incubated on ice. The mixutures were injected on to ABI 310 Genetic analyzer Applied Biosystem (Pensylvania, USA) and electrophoresed.

\section{4) Amplification analysis, $\mathrm{LOH}$}

Electrophoresis was first confirmed with a log file. Using Genescan software, the location and height of tumor/normal samples were chosen and amplified. LOH was analyzed on Genotyper software by the standard of peak height and area.

\section{RESULTS}

\section{Deletion detection result from CGH}

Deletion from CGH was observed on 10q (17\%), 17p (40\%), 18q (47\%), 22q (27\%), and higher deletion loci were 18q (14/30, 47\%), 17p (12/30, 40\%) and 22q (8/30, 27\%), respectively.

\section{Deletion detection result from $\mathrm{LOH}$}

LOH experiments were performed using 9 markers in a manual method and in order to control the quality of the results, we retested the same two markers using the genetic analyzer method. From two experiments, it is confirmed that the experimental results agree with those of the two experimental methods. The results of $\mathrm{LOH}$ detection by microsatellite markers were 57\% (17/30), D18S68 50\% (15/30), TP53CA 50\% (15/30), D18S69 47\% (14/30), D22S274 40 (12/30), D22S283 37\% (11/30), D10S186 27\% (8/30), D10S187 27\% (8/30) and D10S541 $23 \%(7 / 30)$.

\section{The matching rate of deletion with $\mathrm{CGH}$ and $\mathrm{LOH}$}

Based on CGH results, by comparing the concordance rates of the microsatellite markers, D22S274 100\% (8/8), D22S283 100\% (8/8), D10S186 100\% (5/5), D10S187 100\% (5/5), D10S541 100\% (5/5), D18S69 93\% (14/15), D18S68 93\% (13/14), TP53CA 92\% (11/12) and D18S59 89\% $(16 / 18)$ were detected. Based on the positive results in $\mathrm{CGH}$, the concordance rate between the two methods was $94.4 \%$ (85/90), and the overall results by marker were presented (Table 3).

\section{DISCUSSION}

The colorectal carcinoma mortality of Koreans is increasing from 4.5 (per 100,000 persons) in 1990 to 16.4 (per 100,000), showing abrupt rise 3.64 times dramatically [4]. Although the mortality rate of colorectal carcinoma is 4th in the total cancer in Korea, the rate of gastric cancer mortality, which is continuously decreasing, suggests that colorectal cancer is one of the three major cancers in 
Table 3. Summary of CGH : LOH results of colorectal carcinoma

\begin{tabular}{lccrc}
\hline Markers & $\begin{array}{c}\text { CGH detection } \\
\text { detec/case }(\%)\end{array}$ & $\begin{array}{c}\text { LOH detection } \\
\text { detec/case }(\%)\end{array}$ & $\begin{array}{c}\text { LOH/CGH } \\
\text { matching rate }(\%)\end{array}$ & $\begin{array}{c}\mathrm{CGH} / \mathrm{LOH} \\
\text { matching rate }(\%)\end{array}$ \\
\hline D10S186 & $5 / 30(17)$ & $8 / 30(27)$ & $5 / 5(100)$ & $5 / 8(63)$ \\
D10S187 & $5 / 30(17)$ & $8 / 30(27)$ & $5 / 5(100)$ & $5 / 8(63)$ \\
D10S541 & $5 / 30(17)$ & $7 / 30(23)$ & $5 / 5(100)$ & $5 / 7(71)$ \\
TP53CA & $12 / 30(40)$ & $15 / 30(50)$ & $11 / 12(92)$ & $12 / 15(80)$ \\
D18S59 & $18 / 30(60)$ & $17 / 30(57)$ & $13 / 18(89)$ & $18 / 17(106)$ \\
D18S68 & $14 / 30(47)$ & $15 / 30(50)$ & $14 / 15(93)$ & $14 / 15(93)$ \\
D18S69 & $15 / 30(50)$ & $12 / 30(47)$ & $8 / 8(100)$ & $15 / 14(107)$ \\
D22S274 & $8 / 30(27)$ & $11 / 30(37)$ & $8 / 8(100)$ & $8 / 12(67)$ \\
D22S283 & $8 / 30(27)$ & $107 / 270(39.6)$ & $85 / 90(94.4)$ & $8 / 11(73)$ \\
Total (\%) & $90 / 270(33.3)$ & & $90 / 107(84.1)$ \\
\hline
\end{tabular}

LOH/CGH Matching rate (\%): Results based on CGH.

$\mathrm{CGH} / \mathrm{LOH}$ Matching rate (\%): Results based on $\mathrm{LOH}$.

Korea. The cause of colorectal carcinoma in Koreans is expected to increase at a rapid rate due to the westernized eating habits of the US and Western European countries. Therefore, many experiments to find genes related to the development and progression of colorectal cancer have been tried in Korea and abroad, and cytogenetic and molecular genetic techniques have been developed and used [9].

The principle of comparative genomic hybridization (CGH) is that DNA extracts from tumor tissue and normal tissue are labeled with different fluorescent and hybridized with metaphase chromosomes and evaluated by the changes of DNA copy number with the ratio of competitive-combined fluorescence sensitivity [10]. One of the molecular genetic techniques, the principle of the heterozygote deletion experiment, uses microsatellite which is abundantly distributed on the chromosome of the human genome and has high diversity and polymorphism. In other words, the repeated base sequences are applied with markers on chromosome loci. With tumor and normal DNA, they are amplified with PCR, electrophoresis on sequencing gel, perform silver staining, evaluate the ratio of density to determine the ratio of density between each band and finally copied number of tumor genes [11].

In this study, based on the results of the comparative genomic hybridization method, which can select whole genetic alteration, which is involved in the development of colon cancer, LOH test which can detect gene changes in small parts and specific loci of all chromosomes was performed. The coincidence of chromosomal deletion was confirmed from cytogenetic techniques and molecular genetic results. As a result of this experiment, the deletion of chromosome $17 \mathrm{p}$ was found to be $40 \%$ in CGH and 50\% in $\mathrm{LOH}$, which is generally explained as a result of p53 gene deletion. Experimental results were similar to those reported previously. The point mutation and allele loss of the p53 gene is highly prevalent in colorectal carcinoma and is known to play an important role in the development and progression of colorectal carcinoma [12].

The p53 gene binds to a specific part of the DNA and regulates transcription of the gene to inhibit cell division and growth. As a mechanism of inhibition of cell growth, p53 protein stimulates the production of $21 \mathrm{KD}$ cipi or WAF1 protein that inhibits cyclin-dependent kinase, lengthening mitosis G1 and repair damaged DNA. In addition to colorectal carcinoma, there are gene mutations in about $50 \%$ of a wide range of cancers including gastric, lung, and liver cancer. In $75 \%$ of sporadic colorectal carcinoma, one allelic defect and the remaining alleles are mutated. Point mutations are observed in 95\% of colon carcinoma with $\mathrm{LOH}$. The results of this experiment suggest that the detection rate of $\mathrm{LOH}$ is higher than that of $\mathrm{CGH}$ is due to the characteristic $\mathrm{LOH}$ that can detect small parts of defect.

The deletion of chromosome $18 \mathrm{q}$ was found in the highest frequency, $47 \%$ of all genes and 47 to $57 \%$ of $\mathrm{LOH}$ in CGH. This finding is similar to previous report [13]. The 18q gene is well known for the presence of DCC and 
DPC4. It became to be involved in the development of cancer when the DCC gene with mutation fail to function and the normal $18 \mathrm{q}$ allele is lost.

The loss of heterozygosity of the DCC gene has been reported to be closely related to the prognosis, and it has been reported to be an independent prognostic factor in stage II-patients. Another 18q21 defect is characterized by a recurrence of the lesion, which is characterized by a recurrence rate of $82 \%$ in patients with a defec. There is a report that chemotherapy needs to be controlled as a significant survival rate with $\mathrm{LOH}$ results [14]. Therefore, it is appropriate to select the treatment method for the recurrence group. It is known that SMAD4/DPC4 of SMAD2 and 18q21.1, recently known as genes of 18q21 region, plays an important role in the pathway of TGF- $\beta$ which regulates cell growth inhibition signal from cell surface to nucleus. In this study, $47 \%$ of the $\mathrm{LOH}$ test using the LOH marker (D18S69) as a selective marker for 18q21.1, was detected in Korean patients with colorectal carcinoma.

The defect of 22q was found to be relatively high as $27 \%$ in CGH and 37 40\% in LOH. Other reports about the deletion have distinguished between reported and not reported. The results reported in the Japanese population were the highest in 26 56\% [15], while the other reported in Western Europe were reported to be as low as $7 \sim 8 \%$ [16]. This makes it possible to estimate that there is difference in race. Chromosome 22q contains the PCNA gene, which is part of the DNA synthesis enzyme, plays an important role in the synthesis of DNA, and is involved in the repair of DNA damage and the regulation of the cell cycle, which is amplified at a high frequency when the prognosis is bad. Based on the above results, it is considered that the deletion of $17 \mathrm{p}, 18 \mathrm{q}$, and $22 \mathrm{q}$ is a marker of development and prognosis of colorectal carcinoma rather than involvement of metastasis.

The overall detection rate of $\mathrm{LOH}$ was $39.6 \%$. The detection results of $\mathrm{LOH}$ depends on marker on chromosome loci were 10q (23 27\%), 17p (50\%), 18q $(47 \sim 57 \%)$ and $22 \mathrm{q}(37 \sim 40 \%)$, respectively, which is shown a similar result with previous reports [17]. The matching rate between CGH and LOH was 94.4\% (85/90), similar to that reported in other countries (94.5\%) [18]. However, there is no data to compare with colon cancer, and it is unfortunate that it can not be compared with the result of prostate cancer. CGH is a cytogenetic method, kind of dual color fluorescence in situ hybridization (LOH). $\mathrm{LOH}$ is a molecular genetic method and it is a completely different approach to experiment with PCR products. It was judged to be very useful for confirming the experimental results. In addition, fluorescence in situ hybridization (FISH) was performed in laboratories that can not perform $\mathrm{CGH}$, which is considered to be a good method for verifying the reliability of the experiment, although it is limited to compare the results with LOH [19].

The LOH method is divided into a manual method using polyacrylamide gel electrophoresis and a newly developed genetic analyzer method using electrophoresis using capillary. The advantage of the genetic analyzer is that it is able to know the exact size by using the size standard and it is possible to run up to 96 samples at a time. As the graph shows the result, the peak and the area can be known as the score. As shown in the photograph of the $\mathrm{LOH}$ detection result shown in Figure 1, the difference between the alleles can be easily understood by anyone. In addition, it was confirmed that the repeatability of the same specimen was superior to that of the guideline as a quasi-quantitative method reported as only $0.3 \%$ of errors with different results [20]. LOH can be applied not only in experiment but also in clinical practice. In the case of colorectal carcinoma, deletion of 18q21 allele, which characteristically causes recurrence, is useful for the selection of treatment method and prognostic estimation as well as treatment decision. Therefore, it is suggested that LOH using surgical site tissues should be used effectively for the treatment of colorectal carcinoma patients.

The CGH used in this study solves the cytogenetic limitation that can be analyzed only through the cultured cells. It is difficult to cultivate tumor cells, and the chromosomal changes in many cancer cells. These disadvantages could be overcome that it was a very effective way to 

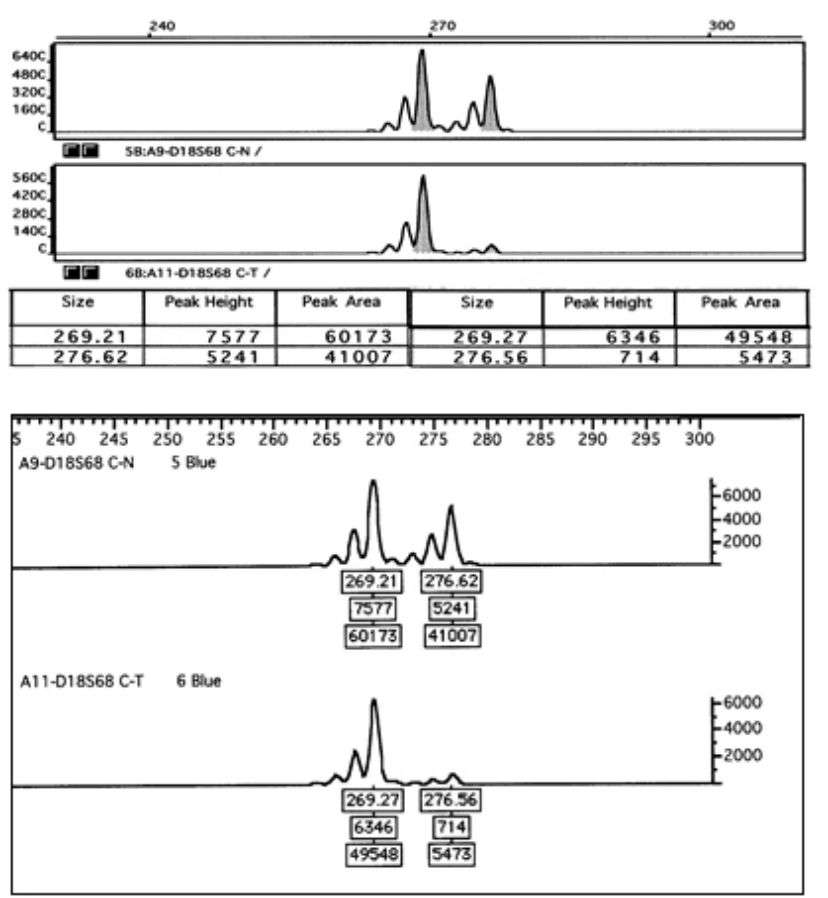

Figure 1. Loss of heterozygosity at various chromosome in colorectal calcinoma by genetic analyzer (genetic analyzer 310). In size 269 , the peak area and peak height of normal and tumor were similar, but in size 276 , the peak area was reduced by $87 \%$ and the peak height was decreased by $86 \%$ in tumor compared to normal. This means that deletion of the allele occurred.

identify changes to the entire chromosome with only one hybridization (Figure 2). Therefore, it was able to select not only the genetically modified parts involved in the colon cancer development but also the change of many genes involved in the development and progression of the tumor. $\mathrm{LOH}$ is a molecular genetic technique that can accurately detect genetic modification of a small region by PCR amplification products using microsatellite markers for specific regions. However, there is a drawback that time and expense are large to target whole chromosomes without specific information. Therefore, based on the advantages of CGH, which can obtain a lot of information about the entire tumor genome at one time, it could be identified the region with significant amplification and deletion from $\mathrm{CGH}$, and the more limited region with $\mathrm{LOH}$ with completely different approach. The information obtained here would be very useful for studying the development mechanism and progress of cancer.

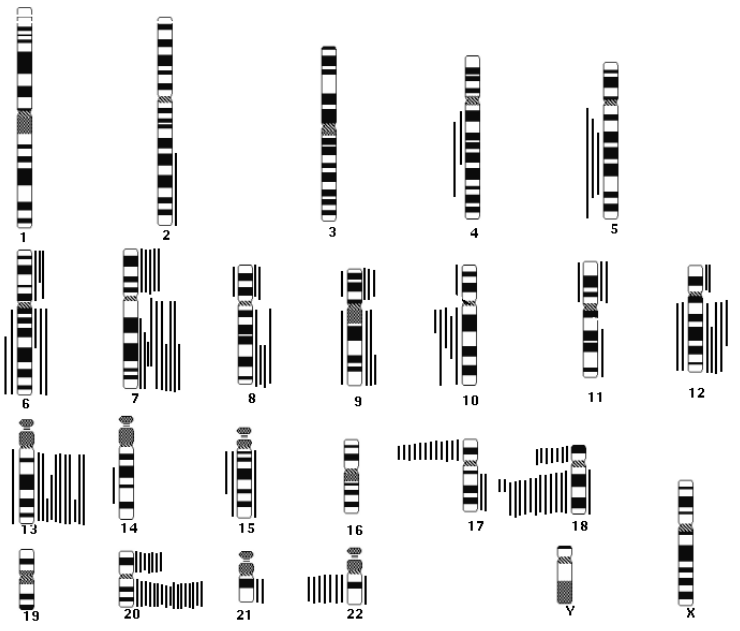

Figure 2. Summary of the genetic imbalances detected by comparative genomic hybridization in 30 colorectal carcinomas. Lines on left of each chromosome represented losses, and lines on the right represented gains. It were shown that 14 deletions in long arm of chromosome 18, 12 deletions in short arm of chromosome17, 8 deletions in long arm of chromosome 22, and 5 deletions in long arm of chromosome 10.

\section{요 약}

대장암은 전 세계적으로 볼 때, 매년 135만명이 발생하고 매 년 60만명이 사망하는 질환으로, 한국에서도 2015년도에 8,380 명이 사망하였으며, 고형 암중에서 가장 높은 증가율을 나타내고 있다.

대장암의 진단과 연구를 위한 다양한 방법 중에서 동일한 검 사 샘플을 이용하여, 세포유전학적인 방법과 분자유전학적인 방법을 통해 얻어지는 결과를 비교하였다. CGH에서 결실은 $18 \mathrm{q} 47 \%, 17 \mathrm{p} 40 \%, 22 \mathrm{q} 27 \%, 10 \mathrm{q} 17 \%$ 이 나타났고, LOH는 D18S59 57\%, D18S68 50\%, TP53CA 50\%, D18S69 47\%, D22S274 40\%, D22S283 37\%, D10S186 27\%, D10S187 $27 \%$, D10S541 23\%순으로 관찰되었다. Microsatellite marker별 일치율은 D22S274 100\%, D22S283 100\%, D10S186 100\%, D10S187 100\%, D10S541 100\%, D18S69 93\%, D18S68 93\%, TP53CA 92\%, D18S59 89\% 순으로 검출되었으며, CGH 에서의 양성결과를 기준으로, 두 방법간의 일치율은 $94.4 \%$ 로 나타났다. 이번 실험은 종양 genome전체에 대한 많은 정보들 을 한 번에 얻을 수 있었던 $\mathrm{CGH}$ 의 장점을 토대로, $\mathrm{CGH}$ 에서 의 미 있게 결실을 보인 부분을, 접근 방법이 전혀 다른 $\mathrm{LOH}$ 로 좀 더 한정된 부위의 변화를 확인할 수 있었을 뿐 아니라, 재발 고위 험군인 18q21의 대립유전자의 소실을 확인하면 치료방법 선정 에 도움을 줄 수 있고, 예후 추정 및 치료 결정에 유용하므로, 대 장암 환자가 수술 시에는 수술 부위 조직을 이용한 $\mathrm{LOH}$ 를 시행 
하여, 재발 고위험군에 대한 치료방법 선정 등 임상에서 효율적 으로 활용하는 것이 필요하다고 사료된다.

Acknowledgements: This paper is supported by the academic research fund of Hyejeon College in 2017.

Funding: None

Conflict of interest: None

\section{REFERENCES}

1. Tariq K, Ghias K. Colorectal cancer carcinogenesis: a review of mechanisms. Cancer Biol Med. 2016;13(1):120-135. doi:10. 28092/j.issn.2095-3941.2015.0103.

2. Viswanath B, Kim S, Lee K. Recent insights into nanotechnology development for detection and treatment of colorectal cancer. Int J Nanomedicine. 2016;2:2491-2504.

3. Yang CY, Lu RH, Lin CH, Jen CH, Tung CY, Yang SH, et al. Single nucleotide polymorphisms associated with colorectal cancer susceptibility and loss of heterozygosity in a Taiwanese population. PLoS One. 2014;26;9(6):e100060. doi:10.1371/ journal.pone.0100060.

4. Korea National Statistical Office, KOSTAT. Statistical Yearbook of Death Statistics. Mortality by cause of death, 1990-2015 [cited 2017 August 6]. Available from: http://kostat.go.kr/ wnsearch/search.jsp

5. Henrikson NB, Webber EM, Goddard KA, Scrol A, Piper M, Williams MS, et al. Family history and the natural history of colorectal cancer: systematic review. Genet Med. 2015;17(9): 702-712.

6. O'Mahoney PR, Scherl EJ, Lee SW, Milsom JW. Adenocarcinoma of the ileal pouch mucosa: case report and literature review. Int J Colorectal Dis. 2015;30(1):11-18. doi: 10.1007/s00384-0142043-3.

7. Sawada T, Yamamoto E, Suzuki H, Nojima M, Maruyama R, Shioi Y, et al. Association between genomic alterations and metastatic behavior of colorectal cancer identified by array-based comparative genomic hybridization. Genes Chromosomes Cancer. 2013;52(2):140-149. doi: 10.1002/gcc.22013.

8. Zauber P, Marotta S, Sabbath-Solitare M. Copy number of the Adenomatous Polyposis coli gene is not always neutral in sporadic colorectal cancers with loss of heterozygosity for the gene. BMC Cancer. 2016;16:213. doi:10.1186/s12885-016$2243-z$

9. Provenzale D, Jasperson K, Ahnen DJ, Aslanian H, Bray T,
Gupta S, et al. Colorectal cancer screening, version 1. 2015. J Natl Compr Canc Netw. 2015;13(8):959-968.

10. Shi ZZ, Zhang YM, Shang L, Hao JJ, Zhang TT, Wang BS, et al. Genomic profiling of rectal adenoma and carcinoma by array-based comparative genomic hybridization. BMC Med Genomics. 2012;5:52.

11. Guo T, Sun JW, Lv QP, Li XG. Allelic imbalance on chromosomes $3 p$, $9 p$ and $17 p$ in malignant progression of laryngeal mucosa. J Laryngol Otol. 2008;122(1):72-77.

12. Datta A, Dey S, Das P, Alam SK, Roychoudhury S. Transcriptome profiling identifies genes and pathways deregulated upon floxuridine treatment in colorectal cancer cells harboring GOF mutant p53. Genom Data. 2016;17(8):47-51.

13. Laczmanska I, Karpinski P, Kozlowska J, Bebenek M, Ramsey D, Sedziak T, et al. Copy number alterations of chromosomal regions enclosing protein tyrosine phosphatase receptor-like genes in colorectal cancer. Pathol Res Pract. 2014;210(12): 893-896.

14. Watanabe T, Wu TT, Catalano PJ, Ueki T, Satriano R, Haller DG, et al. Molecular predictors of survival after adjuvant chemotherapy for colon cancer. N Engl J Med. 2001;344(16): 1196-1206.

15. Nakao K, Shibusawa M, Tsunoda A, Yoshizawa H, Murakami M, Kusano M, et al. Genetic changes in primary colorectal cancer by comparative genomic hybridization. Surg Today. 1998; 28(5):567-569.

16. De Angelis PM, Clausen OP, Schjølberg A, Stokke T. Chromosomal gains and losses in primary colorectal carcinomas detected by CGH and their associations with tumour DNA ploidy, genotypes and phenotypes. Br J Cancer. 1999;80(4): 526-535.

17. Torabi K, Miró R, Fernández-Jiménez N, Quintanilla I, Ramos L, Prat E, et al. Patterns of somatic uniparental disomy identify novel tumor suppressor genes in colorectal cancer. Carcinogenesis. 2015;36(10):1103-1110.

18. Yano S, Matsuyama H, Matsuda K, Matsumoto H, Yoshihiro S, Naito K. Accuracy of an array comparative genomic hybridization (CGH) technique in detecting DNA copy number aberrations: comparison with conventional CGH and loss of heterozygosity analysis in prostate cancer. Cancer Genet Cytogenet. 2004;15;150(2):122-127.

19. Grade M, Becker H, Liersch T, Ried T, Ghadimi BM. Molecular cytogenetics: genomic imbalances in colorectal cancer and their clinical impact. Cell Oncol. 2006;28(3):71-84.

20. Skotheim R, Diep CB, Kraggerud SM, Jakobsen KS, Lothe RA. Evaluation of loss of heterozygosity/allelic imbalance scoring in tumor DNA. Cancer Genet Cytogenet. 2001;127(1):64-70. 